\title{
Redesain Overhead Crane dengan Analisa Kegagalan Di PLTU PAITON Berbasis Metode Elemen Hingga
}

\author{
Alfian Aziz Sahadewa dan Alief Wikarta \\ Departemen Teknik Mesin, Fakultas Teknologi Industri, Institut Teknologi Sepuluh Nopember (ITS) \\ e-mail:wikarta@me.its.ac.id
}

\begin{abstract}
Abstrak-Crane adalah alat bantu yang digunakan untuk mempermudah dalam memindahkan suatu obyek atau barang dengan ukuran yang relatif besar dan berat dari satu posisi ke posisi lainnya. Pada PLTU PAITON Crane digunakan untuk proses maintenace mesin grinding mill. Hoist Grider Crane Mill terkendala ruang gerak yang terbatas. terbatasnya ruang gerak menyebabkan tidak sejajarnya sumbu antara kawat penarik dengan sepesial tool yang menyebabkan beban pengangkatan menjadi $2 \mathrm{x}$ dari beban awal. Akibat tidak sejajarnya kawat overhead crane menakibatkan terjadinya patahan pada housing motor crane yang bertugas untuk menggerakan grider kearah vertikal Oleh karena itu perlu adanya modifikasi overhead girder dengan menggunakan perangkat lunak SolidWorks. Hasil yang diperoleh dari penelitian ini yaitu berdasarkan hasil pengujian, stress, displacement, dan angka keamanan modifikasi 1 memiliki hasil simulasi yang hampir sama dengan hasil dari simulasi awal dengan nilai stress sebesar 36,19 Mpa, Displacement sebear $0,98 \mathrm{~mm}$, dan angka keamanan sebesar 5,7. Pada modifikasi 2 perbedaan hasil simulasi yang paling besar terletak pada simulasi tegangan (stress) sebesar 158,3 Mpa. sedangkan hasil simulasi defleksi dan angka keamanan tidak berbeda jauh dengan simulai awal dimana defleksi sebesar 0,93 dan angka keamanan sebesar 3,1.
\end{abstract}

Kata Kunci-Elemen Hingga (Finite Elemen Analysis), Crane, , Teori Kegagalan, SolidWork, Simulasi.

\section{PENDAHULUAN}

$\mathrm{D}$ ALAM dunia industri, untuk menunjang baik dalam proses pembangunan maupun produksi membutuhkan peralatan yang memadai agar dalam proses pengerjaanya lebih efisien. Pada industri bersekala besar peralatan dan material yang di gunakan relatif berat dan berukuran besar.karena hal itu diperlukannya pesawat angkat seperti crane untuk mempermudah proses pengerjaanya.

Di PLTU Paiton sekitar bulan Juni kemarin karena terjadi patahan fatigue. Overhead crane mengalami patahan pada housing motor crane yang bertugas untuk menggerakan grider kearah vertikal. Patahan terjadi karena terbatasnya ruang gerak yang menyebabkan tidak sejajarnya sumbu antara kawat penarik dengan sepesial tool yang menyebabkan beban pengangkatan menjadi $2 \mathrm{x}$ dari beban awal.

Pada tahun 2014, Eko Warsito melakukan penelitian tentang overhead crane yang berjudul "Analisis Struktur Overhead Crane Kapasitas 35 Ton dengan Modifikasi Tambahan beban 6 Ton". Dalam pengujiannya, peneliti menggunakan metode elemen hingga (FMA) pada software Solidworks. Tujuan dari penelitian ini adalah untuk menganalisa kekuatan struktur kaki-kaki pada saat crane mengangkat beban, untuk mengetahui apakah dengan struktur yang sudah ada perlu penambahan penguat pada kaki-kakinya, dan untuk mengetahui bebaan maksimal yang mampu diangkat oleh crane setelah penambahan beban [1].

Metode elemen hingga adalah metode numeric untuk mempekirakan solusi dari permasalahan matematis sehingga memperoleh hasil yang mendekati dengan kondisi real. Secara garis besar, metode elemen hingga dilakukan dengan cara membagi-bagi suatu struktur menjadi beberapa elemen, dan elemen tersebut terhubung melalui nodal-nodal. Jenisjenis elemen yang digunakan dalam metode elemen hingga adalah elemen satu dimensi (truss elemen, bar elemen, dsb) elemen dua dimensi (plane, plate elemen dsb) dan elemen 3 dimensi (solid elemen) [2]. Pada penelitian ini pengujian dilakukan berdasarkan teori kegagalan Von Mises [3]. Variasi dari modifikasi adalah sebanyak 2 variasi dimana yang nantinya dipilih varian terbaik. Perangkat lunak metode elemen hingga yang hendak digunakan adalah SolidWorks [4].

\section{METODE ANALISA}

\section{A. Data Overhead Crane}

Dimensi dan geometri Overhead Crane origin ditunjukkan pada gambar 1. Data material yang dibutuhkan dalam penelitian ini adalah data material A572 Gr 50. Tabel 1 dan 2 menunjukan komposisi kima dan sifat mekanik yang akan digunakan untuk mencari yield strength seperti gambar 2. Data tersebut merupakan sifat mekanis pada tiap arah dari material tersebut dan dibutuhkan untuk melakukan analisa. Data ini diambil darri referensi yang ada pada internet.

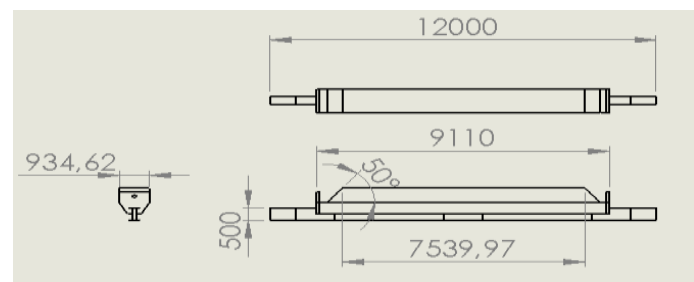

Gambar 1. Dimensi Crane Origin.

Tabel 1.

Komposisi Kimia A572 Gr 50

\begin{tabular}{|c|c|c|c|c|c|c|c|c|}
\hline \multicolumn{7}{|c|}{ A572 Grade 50 Chemical Composition } \\
\hline \multirow{2}{*}{ Grade } & \multicolumn{7}{|c|}{ The Element Max (\%) } \\
\cline { 2 - 9 } & C & Si & Mn & P & S & V & Ni & Co \\
\hline A572 Grade 50 & 0.23 & 0.4 & 1.35 & 0.04 & 0.05 & 0.06 & 0.015 & 0.05 \\
\hline
\end{tabular}

Tabel 2.

Komposisi Mekanik A572 Gr 50 


\begin{tabular}{|c|c|c|c|c|}
\hline Grade & Thickness(mm) & Min Yield (Mpa) & Tensile(MPa) & Elongation(\%) \\
\hline \multirow{2}{*}{ A572 Grade 50 } & $8 \mathrm{~mm}-50 \mathrm{~mm}$ & $345 \mathrm{Mpa}$ & $450 \mathrm{Mpa}$ & $21 \%$ \\
\cline { 2 - 5 } & $50 \mathrm{~mm}-200 \mathrm{~mm}$ & $345 \mathrm{Mpa}$ & $450 \mathrm{Mpa}$ & $18 \%$ \\
\hline \multicolumn{4}{|c|}{ The min impact energy is longitudinal energy } \\
\hline
\end{tabular}

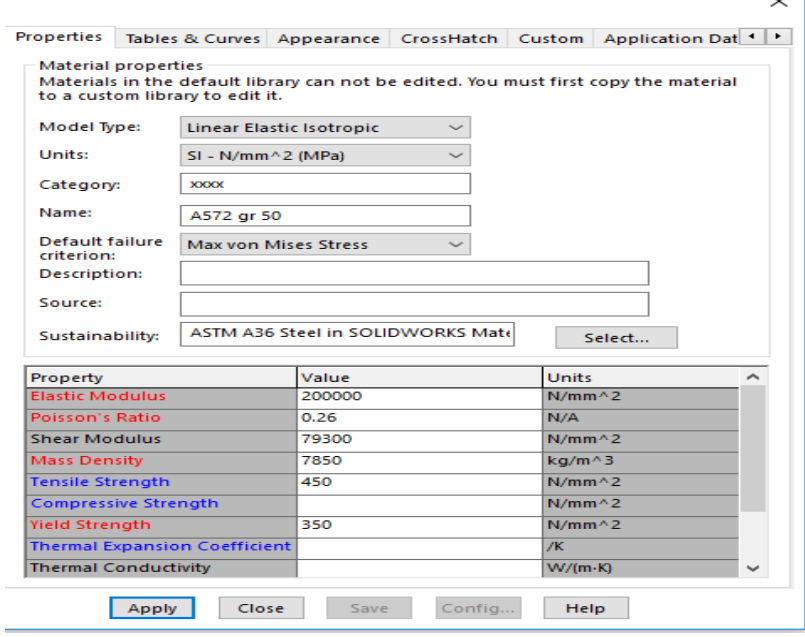

Gambar 2. Jendela Pengaturan Material.

\section{B. Pengujian}

Pada penelitian ini pengujian yang digunakan adalah pengujian stasis yang terdapat pada software SolidWorks. Pada pengujian statis di solidworks terdapat tiga jenis hasil yang akan dianalisa, yaitu teggangan (stress), displacement, dan factor of safety.

\section{Permodelan Metode Elemen Hingga}

Dengan menggunakan bantuan perangkat lunak SolidWorks, maka permodelan Girder Overhead Crane sebagai bentuk solid dapat dilakukan. Selanjutnya, bentuk surface dari fork solid tersebut diambil dari tiap face luar geometri. Gambar 3 menunjukkan bentuk solid dan surface dari Girder Overhead Crane tersebut didefinisikan sebagai A572 Gr 50. Hal selanjutnya yang dilakukan adalah menerapkan boundary condition pada struktur girder. Fixed constraint diterapkan pada bagian sambungan antara gilder dan end truck, dapat dilihat pada gambar 4.

Pemberian beban atau loading dapat dilihat pada Gambar 5. pemberian beban dibagi menjadi 3 bagian yaitu A, B, dan $\mathrm{C}$ dimana tiap beban terdapat 3 kondisi pembebanan seperti pada gambar 6. variasi beban yang akan diberikan adalah 5, 10, 15, dan 20 Ton. Hal itu dilakukan karena pada kondisi lapangan proses maintenace mengalami berbagai macam kondisi pembebanan dan struktur overhead gilder belum pernah dilakukan pengujian untuk mengetahui struktur overhead crane masih layak untuk digunakan atau tidak.

\section{Parameter Analisa}

Pada artikel ini, kegagalan yang terjadi pada struktur girder dianalisa berdasarkan hasil tegangan, defleksi, dan angka keamanan dari simulasi. Hasil dari simulasi tersebut akan berbentuk angka dimana Hasil -hasil tersebut digunakan sebagai acuan batas maksimal yang diguakan sebagai acuan dalam redisain model glider crane. Hasil dari simulasi modifikasi overhead crane kemudian dianalisa dimana dengan cara membandingkan antar tiap modifikasi untuk mencari hasil simulasi yang terbaik. Setelah memperoleh hasil-hasil tersebut barulah diperoleh kesimpulan rancangan manakah yang akan dipilih untuk menjadi referensi untuk pengantian Glider pasa overhead crane.

\section{E. Modifikasi Penelitian}

Memodifikasi (redesain) desain dilakukan untuk mencari rancangan yang optimal pada overhead crane. karena dalam kondisi lapangan bagian body gilder overhead crane mengalami ruang gerak yang terbatas hanya $50 \mathrm{~cm}$. Posisi space overhead girder yang tidak sejajar dengan tempat sepesial tool. Karena terkendala ruang gerak menyebabkan tidak sejajarnya antara kawat dan sepecial tools yang digunakan untuk maintenace. Karena kendala tersebut maka perlu adanya modifikasi desain dimana hanya body gilder saja yang akan dimodifikasi.

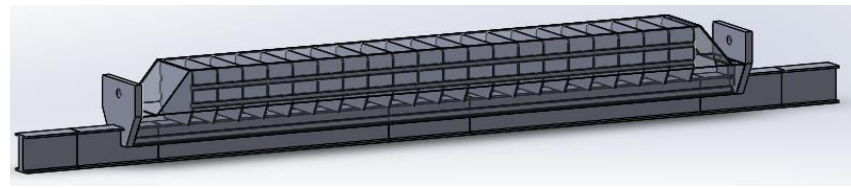

Gambar 3. Crane Origin.

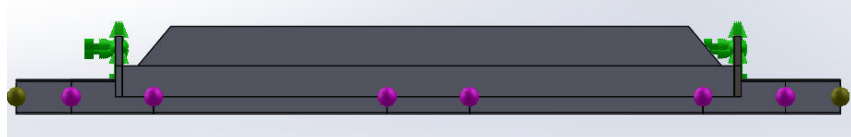

Gambar 4. Penerapan Fixed Constrain.

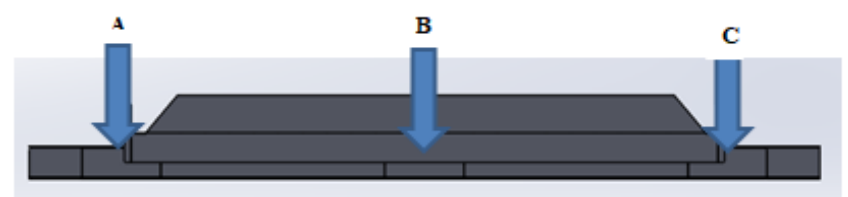

Gambar 5. Pemberian Beban Pada Model.

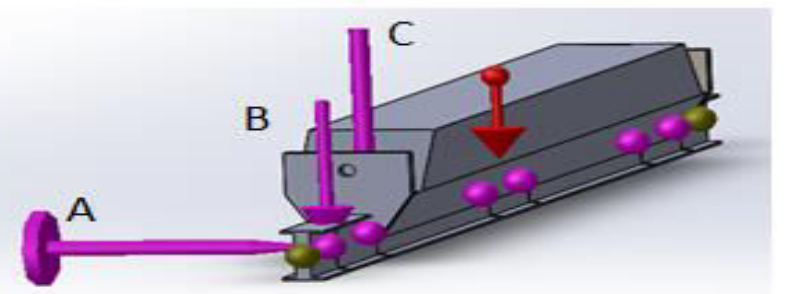

Gambar 6. Beban Momen (a) Beban Motor (b) Beban Total (c).

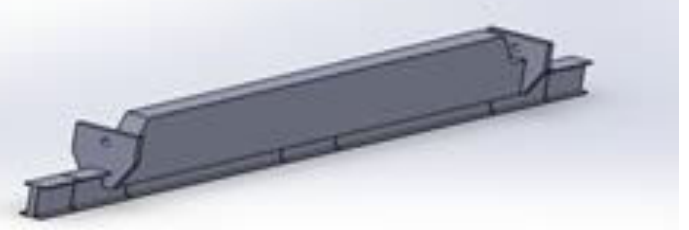

Gambar 7. Modifikasi 1.

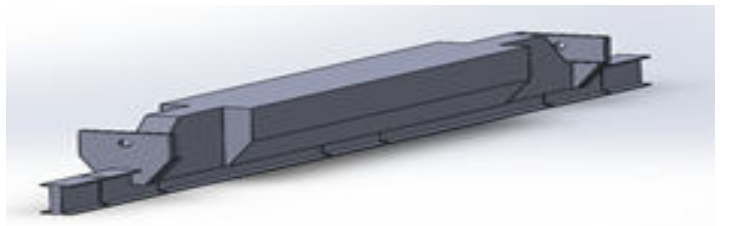

Gambar 8. Modifikasi 2. 


\begin{tabular}{|c|c|c|c|c|c|c|c|c|c|c|}
$\begin{array}{c}\text { Variasi } \\
\text { pembe } \\
\text { banan }\end{array}$ & \multicolumn{3}{|c|}{ STRESS (Mpa) } & \multicolumn{3}{c|}{ DISPLACEMENT } & \multicolumn{3}{c|}{$\begin{array}{c}\text { Angka } \\
\text { Keamanan }\end{array}$} \\
\hline $\mathbf{5}$ & A & B & C & A & B & C & A & B & C \\
\hline $\mathbf{1 0}$ & 16,01 & 22,19 & 13,08 & 0.2169 & 0.4559 & 0.2873 & 21.8 & 6.76 & 11.5 \\
\hline $\mathbf{1 5}$ & 35,19 & 31,72 & 14,61 & 0.4196 & 0.636 & 0.3224 & 8.28 & 4.71 & 10.3 \\
\hline $\mathbf{2 0}$ & 47,51 & 51,25 & 16,15 & 0.6665 & 0.8161 & 0.3579 & 4.88 & 3.62 & 9.3 \\
\hline
\end{tabular}

\section{HASIL DAN DISKUSI}

\section{A. Hasil Analisa Awal}

Hasil-hasil dari simulasi origin pada SolidWorks dikumpulkan ke dalam bentuk tabel. Tabel 3 .

Stress terbesar terdapat pada posisi pembebanan B dengan variasi pembebanan 20 Ton nilai 50,78 Mpa. Pada variasi pembebanan 20 Ton stress terkecil terdapat pada pembebanan $\mathrm{C}$ dengan nilai 17,69 Mpa. Displacemnt terbesar terdapat pada variasi beban 20 Ton pada posisi pembebanan B dengan nilai $0,9964 \mathrm{~mm}$. Sedangkan displacement terkecil pada variasi beban 20 Ton terletak pada pembebanan $\mathrm{C}$ dengan nilai 0,3938 $\mathrm{mm}$. Angka keamanan terendah terletak pada variasi beban 20 Ton dengan posisi pembebanan B sebesar 2,93. Pada variasi pembebanan 20 Ton angka keamanan yang paling besar pada posisi pembebanan $\mathrm{C}$ sebear 8,5. Hasil simulasi diatas digunakan sebagai acuan untuk modifikasi 1 dan modifikasi 2.

\section{B. Evaluasi Modifikasi Pertama}

Modifikasi pertama dilakukan dengan mengubah keseluruhan sayap pada bagian body girder overhead crane. Hasil-hasil dari simulasi origin pada SolidWorks dikumpulkan ke dalam bentuk tabel. Tabel 4 .

Pada tabel 4 dapat diketahui tegangan terbesar pada modifikasi 1 terdapat pada posisi pembebanan di A dengan variasi beban 20 Ton sebesar 36,19 Mpa, tegangan terkecil pada pembebanan C sebesar 17,11 Mpa. Sedangkan defleksi terbesar pada variasi beban 20 Ton terdapat pada pembebanan $\mathrm{B}$ sebesar $0,98 \mathrm{~mm}$, tegangan terkecil terdapat pada pembebanan $\mathrm{C}$ sebebsar $0,33 \mathrm{~mm}$. Angka keamanan terdah pada variasi beban 20 Ton terletak pada Pembebanan B sebesar 5,7 dan angka keamanan terbesar pada variasi beban 20 Ton sebesar 9,6 .

Tabel 4.

Hasil Simulasi Modifikasi Pertama

\begin{tabular}{|c|c|c|c|c|c|c|c|c|c|}
\hline $\begin{array}{l}\text { Variasi } \\
\text { pembe } \\
\text { banan }\end{array}$ & \multicolumn{3}{|c|}{ STRESS (Mpa) } & \multicolumn{3}{c|}{$\begin{array}{c}\text { DISPLACEMENT } \\
(\mathrm{mm})\end{array}$} & \multicolumn{3}{c|}{$\begin{array}{c}\text { Angka } \\
\text { Keamanan }\end{array}$} \\
\cline { 2 - 12 } & $\mathrm{A}$ & $\mathrm{B}$ & $\mathrm{C}$ & $\mathrm{A}$ & $\mathrm{B}$ & $\mathrm{C}$ & $\mathrm{A}$ & $\mathrm{B}$ & $\mathrm{C}$ \\
\hline $\mathbf{5}$ & 8,851 & 15,34 & 9,935 & 0,2 & 0,42 & 0,23 & 29 & 13 & 19 \\
\hline 10 & 17,29 & 22 & 11,87 & 0,452 & 0,6 & 0,27 & 14 & 9 & 16 \\
\hline 15 & 26,66 & 28,65 & 13,81 & 0,7 & 0,79 & 0,3 & 9,3 & 6,9 & 12 \\
\hline $\mathbf{2 0}$ & 36,19 & 35,31 & 17,11 & 0,954 & 0,98 & 0,33 & 6,9 & 5,7 & 9,6 \\
\hline
\end{tabular}

Tabel 5.

Hasil Simulasi Modifikasi Kedua

\begin{tabular}{|c|c|c|c|c|c|c|c|c|c|}
\hline \multirow{2}{*}{$\begin{array}{l}\text { Variasi } \\
\text { pembe } \\
\text { banan }\end{array}$} & \multicolumn{3}{|c|}{ STRESS (Mpa) } & \multicolumn{3}{|c|}{$\begin{array}{l}\text { DISPLACEMENT } \\
(\mathrm{mm})\end{array}$} & \multicolumn{3}{|c|}{$\begin{array}{c}\text { Angka } \\
\text { Keamanan }\end{array}$} \\
\hline & A & B & C & A & B & C & A & B & $\mathrm{C}$ \\
\hline 5 & 20,65 & 64,28 & 26 & 0,2 & 0,7 & 0,3 & 17 & 5,4 & 13 \\
\hline 10 & 51,07 & 103,3 & 32,17 & 0,43 & 1,1 & 0,3 & 6,9 & 3,4 & 11 \\
\hline 15 & 82,52 & 142,4 & 39,13 & 0,68 & 0,67 & 0,33 & 4,2 & 5,8 & 8,9 \\
\hline 20 & 114,2 & 158,3 & 46,11 & 0,93 & 0,8 & 0,37 & 3,1 & 4,8 & 7,6 \\
\hline
\end{tabular}

\section{Evaluasi Modifikasi Kedua}

modifikasi kedua dilakukan dengan mengubah sebagian sayap sekitar plat sebelah kanan dan kiri pada bagian body girder overhead crane. Hasil-hasil dari simulasi origin pada SolidWorks dikumpulkan ke dalam bentuk tabel. Tabel 5 .

Pada tabel 5 tegangan terbesar terdapat pada posisi pembebanan B dengan variasi pembebanan 20 Ton nilai 158,3 Mpa. Pada variasi pembebanan 20 Ton stress terkecil terdapat pada pembebanan C dengan nilai 46,11 Mpa. Displacemnt terbesar terdapat pada variasi beban 20 Ton pada posisi pembebanan A dengan nilai $0,93 \mathrm{~mm}$. Sedangkan displacement terkecil pada variasi beban 20 Ton terletak pada pembebanan C dengan nilai $0,37 \mathrm{~mm}$. Angka keamanan terendah terletak pada variasi beban 20 Ton dengan posisi pembebanan A sebesar 3,1. Pada variasi pembebanan 20 Ton angka keamanan yang paling besar pada posisi pembebanan $\mathrm{C}$ sebesar 7,6.

D. Perbandingan Hasil Analisa Origin dan Modifikasi

Berdasarkan analisa yang dilakukan terhadap girder overhead crane dengan mengunakan metode static test pada SolidWorks didapatkan hasil perbandingan deflesksi, tegangan, dan angka keamanan antara analisa awal dengan modifikasi. Data yang diambil adalah dengan variasi beban 20 Ton pada setiap pembebanan.

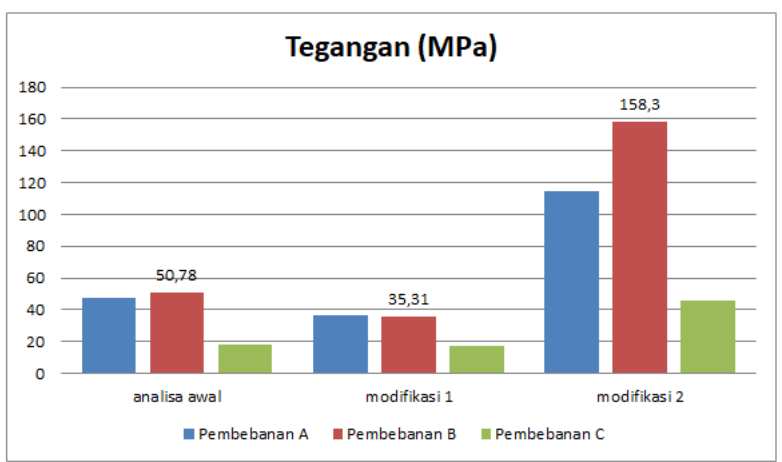

Gambar 9. Grafik Hasil Perbandingan Tegangan Static Bending.

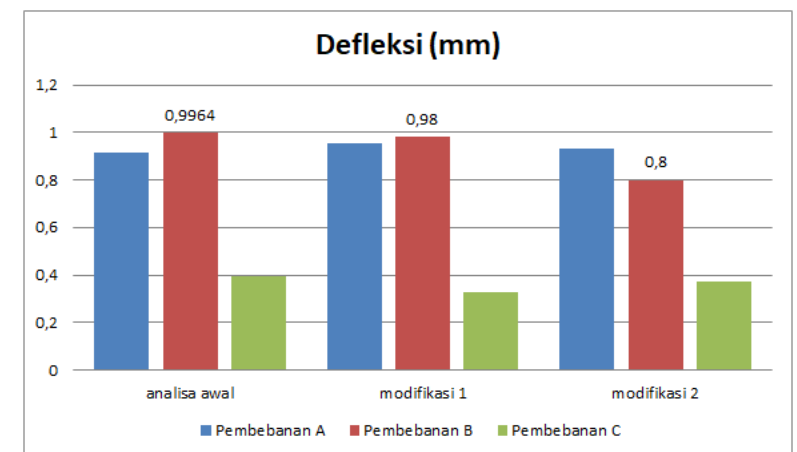

Gambar 10. Grafik Hasil Perbandingan Defleksi Static Bending.

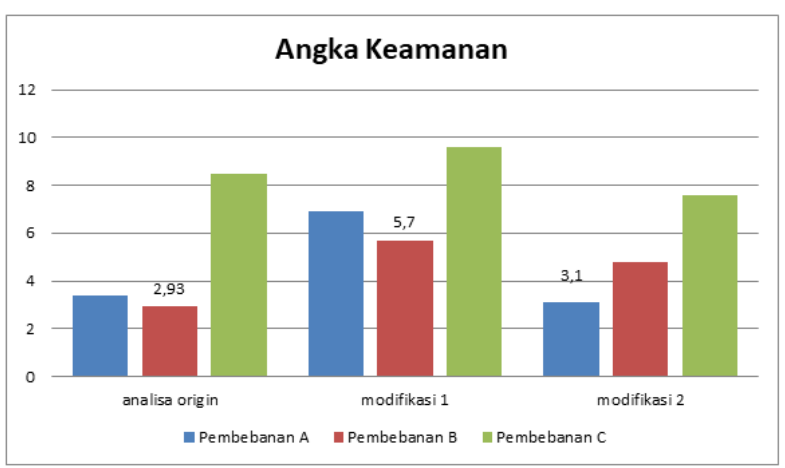

Gambar 11. Grafik Hasil Perbandingan Angka Keamanan Static Bending.

Pada grafik 9 menunjukan tegangan (Stress) analisa origin terbesar terdapat pada pembebanan B sebesar 50,78 Mpa. 
Dari hasil modifikasi 1 dan 2 stress terbesar pada modifikasi 2 stress terletak pada pembebanan B dengan nilai 158,3 Mpa. Tegangan (stress) terkecil terdapat pada pembebanan $\mathrm{C}$ modifikasi 1 dengan nilai 17,11 Mpa. Dari grafik tersebut dapat dilihat bahwa modifikasi 2 memiliki nilai stress yang paling besar melebihi dari analisa awal. Sedangkan pada modifikasi 1 nilai stress yang didapat hampir sama dengan hasil dari modifikasi origin.

Grafik 10 hasil dari simulasi menunjukan defleksi di tiap pembebanan antara analisa awal, modifikasi 1, dan modifikasi 2 tidak jauh berbeda hanya memiliki rata-rata selisih 0,001 mm. Defleksi pada analisa awal terbesar terdapat pada posisi pembebanan B sebesar 0,9964 mm, sedangkan defleski terendah terdapat pada pembebanan $\mathrm{C}$ sebesar 0,3938 mm. Dari modifikasi 1 dan 2 defleksi terbesar terdapat pada modifikasi 1 dengan pembebanan $\mathrm{B}$ sebesar 0,98 mm, sedangkan defleksi terendah terdapat pada modifikasi 1 pada pembebanan $\mathrm{C}$ sebesar $0,33 \mathrm{~mm}$.

Grafik 11 hasil dari simulasi awal menunjukan angka keamanan terendah terletak pada pembebanan B sebesar 2,9 sedangkan akgna keamanan tertinggi terletak pada pembebanan $\mathrm{C}$ sebesar 8,5. Pada modifikasi 1 dan 2 angka keamanan terkecil terdapat pada pembebanan A modifikasi 2 sebesar 3,1. Sedangkan angka keamanan terbesar terdapat pada modifikasi 1 pada pembebanan $\mathrm{C}$ sebesar 9,6.

\section{KESIMPULAN}

Dari tabel analisa diatas yang telah dilakukan, didapatkan kesimpulan sebagai berikut:

1 Berdasarkan pengujian static bending yang telah dilakukan terhadap analisa origin :

a. Tegangan yang terjadi pada tiap pembebanan antara $\mathrm{A}, \mathrm{B}$, dan $\mathrm{C}$ analisa origin terbesar terdapat pada pembebanan B sebesar 50,78 MPa. Tegangan terkecil pada pembebanan $\mathrm{C}$ sebesar 17,69 $\mathrm{MPa}$.

b. Defleksi terbesar pada analisa origin terdapat pada pembebanan B sebesar 0,9964 mm dan defleksi terkecil terdapat pada pembebanan $\mathrm{C}$ sebesar 0,3938 $\mathrm{mm}$.

c. Angka keamanan terrendah terletak pada pembebanan B sebesar 2,93 sedangkan terbesar terdapat pada pembebanan $\mathrm{C} 8,5$.

2 Pada pengujian static bending terhadap modifikasi 1 dan 2: a. Tegangan yang terjadi pada modifikasi 1 terbesar pada pembebanan A sebesar 36,19 Mpa dan tegangan terendah terdapat pada pembeanan $\mathrm{C}$ sebesar 17,11 MPa. Pada modifikasi 2 stress terbesar pada pembebanan B sebesar 158,3 MPa dan tegangan terendah terdapat pada pembeanan $\mathrm{C}$ sebesar 46,11 MPa.

b. Defleksi yang terjadi pada pada modifikasi 1 terbesar pada pembebanan B sebesar 0,98 mm dan defleksi terendah terdapat pada pembeanan $\mathrm{C}$ sebesar 0,33 mm. Pada modifikasi 2 defleksi terbesar pada pembebanan A sebesar $0,93 \mathrm{~mm}$ dan defleksi terendah terdapat pada pembeanan $\mathrm{C}$ sebesar 0,37 $\mathrm{mm}$.

c. Angka keamanan (FoS) terendah yang terjadi pada modifikasi 1 terdapat pada posisi pembebanan B sebesar 5,7. Sedangkan angka keamanan terbesar terdapat pada pembebanan C sebesar 9,6. Pada modifikasi 2 angka keamanan terendah terdapat pada posisi pembebanan A sebesar 3,1. Sedangkan angka keamanan terbesar terdapat pada pembebanan $\mathrm{C}$ sebesar 7,6.

3 Setelah dilakukan simulasi terhadap analisa origin dan seluruh modifikasi pada pengujian static bending :

a. Tegangan yang paling besar terdapat pada modifikasi 2 dimana melebihi dari nilai hasil simulasi origin. Sedangkan pada modifikasi 1 hasil simulasi tidak jauh berbeda terhadap simulasi awal.

b. Perbandingan hasil simulasi terhadap simulasi origin dan modifikasi 1 dan 2 tidak jauh berbeda hanya memiliki rata-rata selisih $0,001 \mathrm{~mm}$.

c. Perbandingan angka keamanan antara simulasi origin dan modifikasi 1 dan 2, modifikasi 2 lebih rendah daripada modifikasi 1 .

Jadi dapat disimpulkan dari perbandingan hasil diatas didapatkan modifikasi 1 lebih layak untuk dipilih sebagai alternatif dalam redesain overhead crane.

\section{DAFTAR PUSTAKA}

[1] E. Warsito, “Analisisi Struktur Overhead Crane Kapasitas 35 Ton Dengan Modifikasi Tambahan Beban 6 Ton," Institut Teknologi Sepuluh November, 2014

[2] D. L. Logan, A First Course in The Finite Element Menthod. Platteville. University of Wisconsin.

[3] R. C. Hibbeler, Mechanics of Materials. United State of America.

[4] SolidWork Corporation, "Solidworks 2016," 2016. 